\title{
The Unexpected Long-Run Impact of the Minimum Wage: An Educational Cascade
}

\author{
Richard Sutch \\ University of California, Riverside, \\ and \\ National Bureau of Economic Research
}

To appear as Chapter 13 in

Paul W. Rhode, Joshua L. Rosenbloom, and David Weiman, editors, Economic Evolution and Revolution in Historical Time, Stanford University Press, 2010

Draft - 7 January 2010

\begin{abstract}
Neglected, but significant, the long-run consequence of the minimum wage requirement - which was made national policy in the United States in 1938 - is its stimulation of capital deepening. This took two forms. First, the engineered shortage of low-skill, low-paying jobs induced teenagers to invest in additional human capital - primarily by extending their schooling - in an attempt to raise their productivity to the level required to gain employment. Second, employers faced with an inability to legally hire low-wage workers, rearranged their production processes to substitute capital for low-skill labor and to innovate new technologies. This chapter explores the impact of the minimum wage on enrollments between 1950 and 2003. I describe an upward ratcheting mechanism which triggers an "educational cascade." My estimate is that the average number of years of high school enrollment would have risen to only 3.5 years, rather than 3.7 years, for men born in 1951 (17 in 1968). Thereafter, enrollment rates would have trended down to about 3.2 years for the cohort born in 1986, rather than slowly rising to around 3.9 years. The cumulative effect of the minimum wage increases beginning in 1950 was to add 0.7 years to the average high school experience of men born in 1986.
\end{abstract}

I have benefited from the suggestions offered by participants at the Washington Area Economic History Seminar (March 2008), the NBER's "Development of the American Economy" Summer Institute (July 2008), the Conference on Historical Approaches to Economics at Stanford University (September 2008), and the Bay Area Colloquium on Population (March 2009). Todd Sorensen made helpful suggestions after a close reading of an early draft. Susan B. Carter has followed this project from its inception. Her advice and encouragement are especially appreciated. 
Except perhaps for the Social Security Act, [the Fair Labor Standards Act] is the most far-reaching, the most far-sighted program for the benefit of workers ever adopted here or in any other country.

Franklin D. Roosevelt, "Fireside Chat," June 24, 1938. ${ }^{1}$

The minimum wage is a contentious and emotional issue in the United States and it has been for almost a century. ${ }^{2}$ A short-hand version of the issue at stake was famously stated by Milton Friedman in Playboy magazine: "A minimum-wage law is, in reality, a law that makes it illegal for an employer to hire a person with limited skills" [1973]. ${ }^{3}$ Proponents, of course, argue that the purpose of a minimum wage is to ensure that every (covered) worker earns an income that can purchase at least the bare necessities of good health and a "living decent according to the standard of the time," a living, in the words of Franklin Roosevelt, "which gives man not only enough to live by, but something to live for."4 Framed in this way, the minimum wage has been a cause for political battle between Democrats (pro) and Republicans (con) whenever it has been raised at the federal, state, or local level. ${ }^{5}$ That means it has been almost continuously the object of heated debate. This political passion is a bit curious since most experts for many years

\footnotetext{
${ }^{1}$ Montrose J. Moses, editor, The Fireside Chats of Franklin Delano Roosevelt, Project Gutenberg, 2002.

${ }^{2}$ Massachusetts was the first state to adopt a minimum wage law in 1912. It was a "recommendatory" law that applied only to women and minors [Kelley 1912]. In 1935 this was replaced with a mandatory law and in 1946 the law was amended to apply to men [US Department of Labor 1967: 93-95]. The minimum wage became federal law with the passage of the Fair Labor Standards Act of 1938. The federal minimum wage applied uniformly to all covered employees (male and female) in all regions of the country.

${ }^{3}$ Geoffrey Norman, “Playboy Interview: Milton Friedman," Playboy 28(2), February 1973: 51-68 and 74. Reprinted in Milton Friedman [1983: 9-59]; the quote is from page 16. The Friedman quote is famous enough to be an entry in the Yale Book of Quotations [Shapiro 2006: 292].

${ }^{4}$ Franklin D. Roosevelt, "Speech before the 1936 Democratic National Convention," Philadelphia, Pennsylvania, June 27, 1936. The speech is more famously titled "A Rendezvous With Destiny."

${ }^{5}$ For the political and legal history of the minimum wage through 1996 see Jerold Waltman [2000: Chapters 2 and 5]. Also see U.S. Department of Labor [1967: 69-100] and Nordlund [1997]. Gavin Wright and Joshua Rosenbloom and William Sundstrom place the origin of the minimum wage in the context of the "high-wage national regime" that lasted for fifty years following World War I and that induced the coinciding period of rapid productivity growth and rising educational attainment [Wright 2006: 143-147, Rosenbloom and William Sundstrom 2010: 24-29 in ms; also see Levy and Temin 2010 and Goldin and Katz 2008]. 
have regarded the minimum wage as a largely irrelevant institutional hangover from the New Deal. ${ }^{6}$

The legislated minimum has frequently been so low relative to prevailing wages that few workers or occupations are affected. The U.S. Bureau of Labor Statistics estimated the fraction of employed wage and salary workers with earnings at or below the Federal minimum wage in 2005 at only 2.5 percent [U.S. BLS 2006: Table 1, also see Haugen and Mellor 1990]. ${ }^{7}$ In 1938 the national minimum wage was set at 25 cents per hour which was raised to 30 cents the following year and, according to Gavin Wright, had a major impact in the South particularly for blacks working in textiles and tobacco [1986: 219-220], but soon thereafter the minimum wage was "repealed by inflation," as George Stigler remarked in 1946 [p. 358]. From time to time, Congress has increased the nominal minimum wage and expanded the coverage of the law. In 1950 it was increased from 40 to 75 cents per hour. In July of 2008 it became $\$ 6.55$ with a further increase in July 2009 to $\$ 7.25$. See Table 1 for a tabulation of all of the changes. These periodic decisions by Congress succeeded in increasing the real value of the wage floor until 1968, but thereafter the legislated increases have failed to catch up or keep up with

\footnotetext{
${ }^{6}$ Charles Brown, a University of Michigan labor economist and a veteran of the minimum wage debates in the academy, stated the case for relative unimportance twenty years ago in his paper "Minimum Wage Laws: Are they Overrated?" [1988]. David Card and Alan Krueger forcefully and persuasively argued that increases in the minimum wage did not lead to a corresponding loss of jobs nor an increase in unemployment [1995]. David Neumark and William Wascher are associated with the argument that minimum wages reduce job opportunities for teenagers, yet they report that their 1992 article did "not reveal disemployment effects of minimum wages for teenagers" [1995a: 199]. For a sampling of journalistic reports see the following, all from the New York Times and all suggesting that the minimum wage has or would have minimal economic consequences: Peter Passell [1989]; Susan Raskey, "The Minimum-Wage Fight Isn't Really About Pay" [1989]; Louis Uchitelle [1990 and 1995]; Robyn Meredith, "Politics Aside, Economy Is Shrugging Off Rise to \$4.75" [1996]; and Peter Kilborn, “A Minimal-Impact Minimum Wage" [1997]. Passell, an economic historian before he became a journalist, cites the research of Alison Wellington, who found little or no impact of the minimum wage on employment [Wellington 1991]. Raskey attributed to Isabel Sawhill, a labor economist at the Urban Institute, the opinion that the minimum wage "isn't going to make a big difference one way or the other." Uchitelle [1995] quotes Nobel laureate Robert Solow: "The main thing about this research is that the evidence of job loss is weak, and the fact that the evidence is weak suggests that the impact on jobs is small." Meredith quotes Barry Bosworth, an economist at the Brookings Institution: "The whole issue is overblown."

${ }^{7}$ The incidence is much higher for teenagers, the focus of this report. The 2005 estimate for teenagers is 8.8 percent.
} 
inflation. See Figure 1 which plots the federal minimum wage measured in terms of the prices of 2007.

In early studies econometricans who attempted to measure the impact of the minimum wage on employment generally reported only a small effect and that only for teenagers. A careful review by Charles Brown, Curtis Gilroy, and Andrew Kohen considered 18 pre-1982 studies each of which employed a time-series analysis of published data derived from the Current Population Surveys (CPS). All 18 reported a negative impact on teenage employment. The point estimates suggested that a 10-percent minimum wage increase would reduce teenage employment by between 0.5 and 3.0 percent [Brown, Gilroy, and Kohen 1982: 505; also see the update in Brown 1999]. However, Brown and his coauthors regard the lower part of the range as most plausible because they regard the tests that produced the lower numbers to be the better specified. Studies conducted in the 1980s and early 1990s reduced the estimate of the negative impact on teenage employment induced by a 10-percent increase in the minimum wage to less than 1 percent [Solon 1985, Adams 1989, Wellington 1991; Card and Kruger 1995: 180-182, 194-204]. Because the teenage employment rate averages about 45 percent, a reduction of 1 percent corresponds to a reduction of 0.45 percentage points in the employment rate, a small effect. Taken together these studies do not allow us to reject the proposition that the true effect is zero. There seems to be no discernable evidence of an impact on employment overall. ${ }^{8}$

Quite apart from the issue of whether the minimum wage leads to job loss, I suggest that a neglected, but significant, consequence of the minimum wage requirement is its stimulation of capital deepening. This took two forms. First, the engineered shortage of low-skill, low-paying jobs induced teenagers to invest in additional human

\footnotetext{
${ }^{8}$ David Card and Alan Kruger launched a devastating critique of the empirical literature I have just summarized [1995: Chapters 6 and 7]. They conclude that the previous estimates are not robust and that "the conventional view that increases in the minimum wage necessarily have an adverse effect on employment has very weak empirical foundations" [pp. 236-237].
} 
capital - primarily by extending their schooling - in an attempt to raise their productivity to the level required for employment. Second, employers faced with an inability to legally hire low-wage workers, rearranged their production processes to innovate new technology and substitute capital for low-skill labor. This essay will focus on the first phenomenon, the impact on educational attainment.

I begin from the premise that the debate over the employment effects of the minimum wage has been misfocused. A labor market with a binding minimum wage is out of equilibrium. In that situation, the alternative to employment for many teenagers is to stay in school. Thus the long-run impact of the minimum wage might well be to increase the stock of human capital: a clearly beneficial, if unexpected, consequence of the minimum wage policy. Yet the impact of the minimum wage on employment is in any case agreed to be rather slight, so one might suggest that any supposed impact on increasing the level of educational attainment is likely to be slight as well. I suggest, however, that there are two reasons to believe that the effect might be strong. First, the minimum wage does have a significant bite for teenagers. I also propose an additional point. There is a ratchet mechanism through which the initial response to a change in the minimum wage can trigger an "educational cascade" producing a sustained increase in educational attainment.

To visualize how a cascade might operate, consider a cohort of 15-year old highschool students most of whom would be enrolled in the tenth grade. Each must make a decision about whether to continue to the eleventh grade. The alternative to school is to join the labor force or to voluntarily join the non-employed. ${ }^{9}$ One economic factor that would influence this decision would be the local unemployment rate of teenagers. Since 15-year olds are not likely to look these statistics up at the library or even read about them in the newspaper, we suppose they form an impression of employment possibilities

\footnotetext{
${ }^{9}$ For the student who decides to stay enrolled, part-time (after-school) employment is also a possibility. As a possible motive to drop out, an alternative to a legitimate job is to join the underground economy and to engage in criminal activities with a pecuniary reward (drug dealing, prostitution, theft) [Freeman 1996]. My focus is on the enrollment decision, not the labor-force status or occupation of the teenager. 
by observation of the experiences of those like themselves in the local job market. Thus the relevant unemployed rates would be those for individuals of the same race, gender, and locality - those of the individual's likely "role-model" group. Thus a black 15-year old male would be likely to consider the job-market experiences of the 16- to 19-year old black men who were not in school in his locality.

There would be another peer-effect on the school-versus-labor-force decision coming directly from the student's classmates. Dropping out would be a significant and probably difficult decision. For most it will be irreversible [Card and Lemieux 2000: 8-9 and Table 1]. In such a situation it is natural that the student would consult and often mimic his peers. If more of the high school students our 15-year-old knows stay in school and go on to the next grade, he will be encouraged to continue as well.

Role-model and peer effects are not the only influences on the school attendance decision. I presume that the opportunity cost of going to school will influence the decision. The opportunity cost will be largely driven by the wage the student can expect if he takes a job. What a binding minimum wage will do is to dramatically lower the opportunity cost of schooling for those whose skills do not yet warrant receiving the minimum wage. In a job market with a high minimum wage, the earning prospects of a student with sub-minimum skills are nil. ${ }^{10}$ Thus an increase in the minimum wage should reduce the dropout rate for this cohort by lowering the opportunity cost of staying in school.

\footnotetext{
${ }^{10}$ I am skirting the issue that not all jobs are covered by the federal minimum wage law. The original law covered workers in private industries engaged in interstate commerce or the production of goods for commerce. It excluded such major sectors as agriculture, retail trade, and service [Douglas and Hackman 1939: 29-33]. Effective in 1950 coverage was reduced by narrowing the meaning of production for interstate commerce. In 1961 employees of retail establishments with sales over \$1 million were added. In 1967 employees of schools, colleges, hospitals, hotels, restaurants, and laundries and employees of large farms were added. In addition the retail sales volume test was reduced to $\$ 250,000$ [Frankel 1966, Waltman 2000: 46]. By 1968 coverage of wage workers by the federal law was reasonably complete and many states had their own minimum wage laws that extended protection to those not covered by the federal law. Moreover, there is some evidence that many (most?) employers who are not required to pay the minimum wage do so nonetheless [Card and Krueger 1995: 158, Fritsch 1981, Uchitelle 1990, Katz and Krueger 1991, 1992].
} 
As I envision this mechanism moving forward in time, a feedback would then produce a ratchet effect operating on the next cohort. If the minimum wage increase causes a greater fraction of the tenth-grade class to stay in school, then the next year's tenth graders will see a greater number of their peers staying in school than would have been the case without the minimum wage increase. Thus even without further minimum wage increases the dropout rate will remain lower than it would have been otherwise. In principle this ratchet effect can influence educational trends for several, perhaps many, years. However, if inflation and productivity increases begin to erode the bite the minimum wage takes out of the lower tail of the wage distribution, the forces supporting the reduction in dropout rates would become attenuated. Another increase in the minimum wage would be necessary to revive the effect.

As educational attainment rises over time, it will generate a scarcity of low-skilled laborers whose employment would be warranted at the minimum wage relative to the skill distributions that characterized the past. One consequence is that this relative shortage would induce employers to substitute capital for low-skilled workers. Think about the computer-assisted order kiosk in a fast-food restaurant. The take-out clerk can punch in the customer's order which immediately flashes on a computer screen in the kitchen and automatically computes the bill and the amount of change to return and even prompts the clerk to ask if the customer would like the order "super-sized" or to suggest a side of fries. A consequence of the capital-labor substitution is to raise the productivity of workers with limited skills. Thus, increasing the minimum wage should work to increase the productivity of those at the bottom of the skill distribution. ${ }^{11}$

If not counteracted, a shortage of low-skilled workers combined with a rising productivity of low-skilled workers operating with more sophisticated capital might drive up the market-clearing wage for low-skilled workers and thus erode the bite of the

\footnotetext{
${ }^{11}$ The argument that a minimum wage would stimulate technological innovation was made by Sydney Webb [1912: 981-983]. The mechanism might also work in reverse. Gavin Wright has suggested that the decline in the real minimum wage evident in Figure 1 after the 1960s was one element contributing to the productivity slowdown in the 1970s [Wright 2006: 152-153].
} 
minimum wage and slow down or even halt the educational cascade. However, in a global economy with open boarders the shortage of low-skilled domestically-educated workers would stimulate the immigration of such workers from abroad, thus widening the wage distribution and increasing the returns to additional education of the native born. Immigration (documented or not) then will serve to prevent a stifling of the long-run educational impact of a minimum wage increase. Another possibility is that the shortage of low-skilled workers will induce producers to import goods and services with low skill content from suppliers abroad, thus producing much the same beneficial impact on school attendance as immigration.

Too much of the theoretical literature on the minimum wage has assumed that low-skilled workers are homogeneous. In the scenario I have just sketched, I assume - as seems realistic - that high school students are heterogeneous in the distribution of their job-relevant skills. I illustrate the point in Figure 2. The bell curve represents the hypothesized distribution of skills (in real terms) of students still enrolled in high school in period $t$ facing an increase in the minimum wage from $\mathrm{MW}_{\mathrm{t}}$ to $\mathrm{MW}_{\mathrm{t}+1}$. For ease of reference, I will place high school students into three groups. Some, who I will call "the relative skillful," have skills such that - in a suitable job - would contribute sufficient product at the margin to warrant more than the proposed minimum wage. At the other extreme are the "sub-minimal" students who have skills (or a maturity) so low that they could not be productively employed at any job paying the current minimum wage. At an intermediate position, the "marginal group" would be able to secure productive employment at the current minimum but unable to do so at the higher minimum.

The enrollment decision of the skillful and sub-minimal students would be unaffected by the proposed change in the minimum wage. It would be marginal students who would be shut out of the labor market by an increase in the minimum wage and thus see the opportunity cost of their schooling fall. Note that in periods where the nominal minimum wage is constant, the marginal group collapses to a razor thin slice. 
This distribution of job-relevant skills is not the same as the distribution of academically-relevant abilities. An individual student's position in the distribution depicted in Figure 2 would not be static. It will shift rightward as time goes on. Additional schooling will enhance job-related skills and move the individual to the right. How effective additional schooling will be in moving the student to higher skill levels will depend - presumably - upon the student's academic abilities. The higher those attributes, the higher the perceived return to continued enrollment. That is why not every relatively-skillful student will take a job. Some will, of course, but their lower academic promise may be the cause. $^{12}$

I can also illustrate the influence of the introduction of new technologies and higher capital-labor ratios on the three groups. Labor productivity would be raised by those phenomena, shifting the entire distribution to the right (relative to the $\mathrm{MW}_{\mathrm{t}}$ and $\mathrm{MW}_{\mathrm{t}+1}$ lines) and caring every student with it. That would sweep some marginal students into the relatively-skillful group where those with low academic potential will be tempted to drop out. To prevent the consequent decline in enrollments, the minimum wage would have to be adjusted upward to at least keep up with productivity advances.

The educational cascade I am describing is not incompatible with the proposition that a minimum wage increase would have no negative employment consequences. If everyone employed before the increase retained his or her job and if every vacancy created by voluntary attrition were filled, it would still remain the case that a law that makes it illegal for an employer to hire a person with sub-minimal skills would shut the student in the marginal group just described out of the market and thus lower the opportunity cost of remaining in school.

\footnotetext{
${ }^{12}$ Poverty or a temporary setback might force some academically promising students in the skillful group to drop out. If so, the fault would be imperfect capital markets that make it impossible or prohibitively expensive to borrow with only academic promise as collateral. 
This report will explore the connections linking the minimum wage and educational attainment using a variety of data sources. It will set aside for another project the impact of the minimum wage on inducing investments in physical capital, spurring technological innovation, or stimulating an increase in low-skilled immigration. Compared to the quite extensive literature on the employment effects of the minimum wage, there has been very little empirical work on the impact of the minimum wage on schooling. ${ }^{13}$

To explore the enrollment consequences of an increase in the minimum wage I turn to two different sources of data. For the period 1968 to the present I use the microlevel data drawn from the public-use files of the October Survey of Current Population [Unicon Research 2007]. Although the school enrollment questions associated with the October surveys date back to 1947, only the published summaries are available for the years before 1968. For the period before 1972, I use the micro-level data in the Integrated Public Use Microdata Series (IPUMS) drawn from the enumerators' manuscripts of 1980, 1970, and 1960 censuses of the U.S. population [Ruggles et al 2008]. The two data sources are quite different. They pose unique complications and offer unique opportunities. I will treat them separately, beginning with the more recent. This partition by data source is unfortunate because coincidentally the general trend of the national real minimum wage has been downward since 1968, while it was generally rising between 1950 and 1968 [see Figure 1]. In what follows I make my best effort to adjust for the changes in my evidentiary bases.

\footnotetext{
${ }^{13}$ I know of only a few prior studies. James Ragan in a passing footnote reported a time-series regression in which the unemployment rate and the minimum wage rate had no impact on school enrollment to justify an assumption to that end [1977: fn 17]. Peter Mattila has made an argument that is in part similar to mine [1981]. "There is good reason to believe that school enrollment may be affected. If minimum wages create barriers to employment, then additional schooling may be one strategy for over-coming that barrier ..." [1981: 61]. David Neumark and William Wascher [1995a, 1995b, and 2003] reach an opposite conclusion. They report that "the minimum wage reduces the proportion of teenagers in school." However, they emphasize the preliminary nature of their results and suggest that the topic "merits further scrutiny" [Neumark and Wascher 2003: 9].
} 
It should also be noted that throughout the entire period some states enacted minimum wage laws that exceeded the federal minimum established by the Fair Labor Standards Act and its amendments. See Figure 3. When the state law established a minimum wage that exceeded the federal minimum, the state law takes precedence. We will exploit the information inherent in the interstate variance in the legal minimum in what follows.

\section{Post-1971 Tests for Impact of Changes in the Federal and State Minimum Wage Laws}

For parsimony's sake - I begin with a look at changes in the federal minimum wage rate before turning to the variation in state laws. Before the latest (2007-2009) round of minimum wage increases, there are four episodes that we can examine with the October CPS data. For ease of identification, I label the rounds of increases with the name of the President who signed the corresponding minimum wage bill: ${ }^{14}$

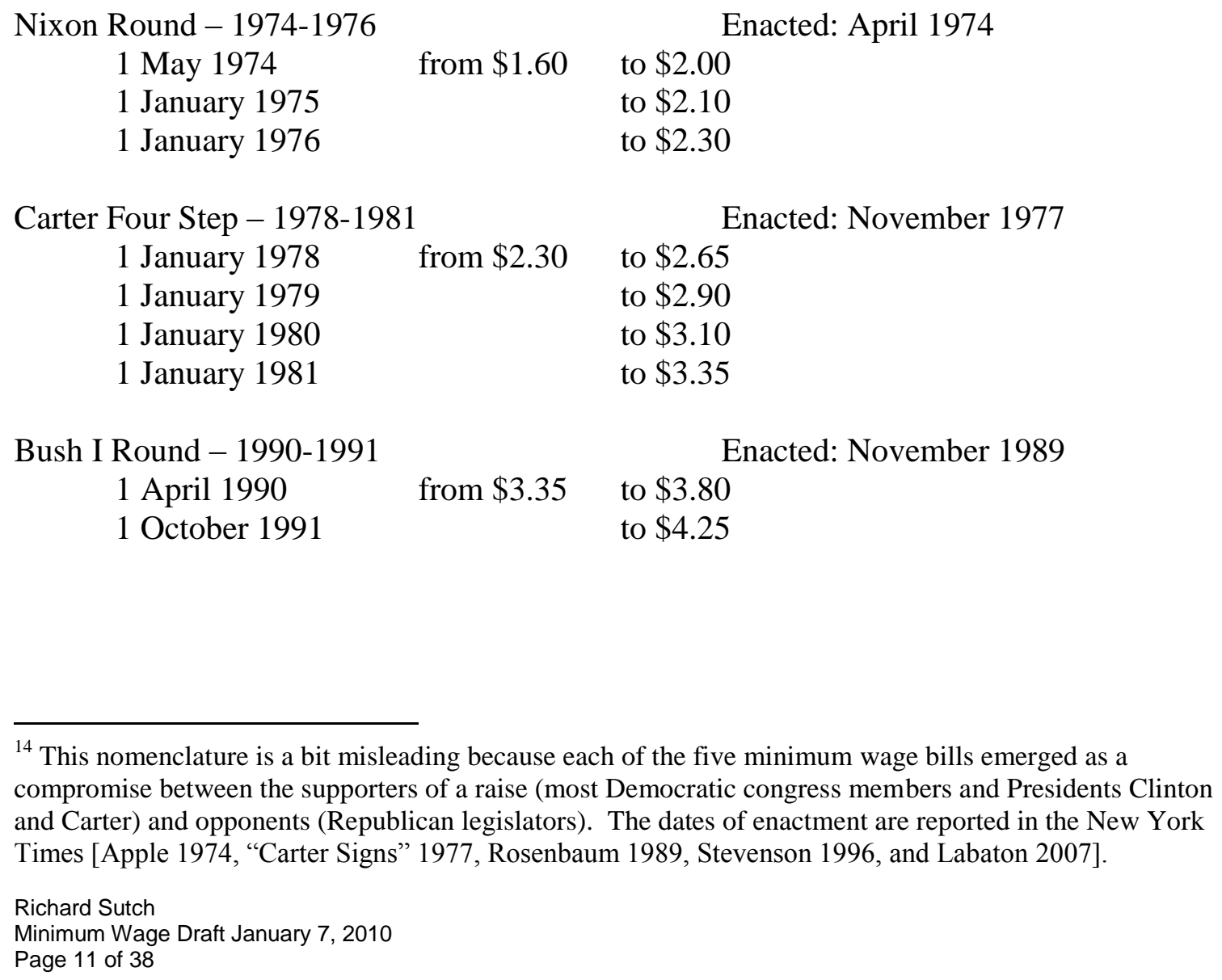

\footnotetext{
14 This nomenclature is a bit misleading because each of the five minimum wage bills emerged as a compromise between the supporters of a raise (most Democratic congress members and Presidents Clinton and Carter) and opponents (Republican legislators). The dates of enactment are reported in the New York Times [Apple 1974, “Carter Signs” 1977, Rosenbaum 1989, Stevenson 1996, and Labaton 2007 ]. 
Clinton Round - 1996-1997

1 October 1996

1 September 1997

Bush II Round - 2007-2009

24 July 2007

24 July 2008

24 July 2009
Enacted: August 1996

from $\$ 4.25$ to $\$ 4.75$

to $\$ 5.15$

Enacted: May 2007

It is important to examine these federal changes by rounds since the second, third, and fourth steps can be anticipated as of the date the first step is enacted. Thus forewarned, the impact of the subsequent steps may influence student decisions before they actually take effect.

I use the October surveys from the CPS because they contain detailed questions about education; in particular there is the response recorded to a question about the school grade attended. ${ }^{15}$ This information was recorded for everyone aged 3 and older. The CPS surveys recognized four grades of "high school" defined as $9^{\text {th }}$ through $12^{\text {th }}$ grade. By merging the October results for all the available years (1968-2006) I can follow a birth cohort from year to year. A student who was 15-years old in October 1968 would be 16 in 1969, 17 in 1970, and so on. A birth cohort series assembled in this manner describes a "statistical" rather than a true cohort since we have a sample of 15 year-olds in 1968 and a separate sample of 16 year olds in 1969 which would include many individuals not surveyed in the previous year. ${ }^{16}$ But if the samples are representative, then the time series identified as the birth cohort of 1953 can be said to represent the experience of those who were born between 15 October 1952 and 14 October $1953(1953+13=1968)$ and who survived into the following year.

\footnotetext{
${ }^{15}$ No distinction is made in the CPS between enrollment and attendance.

${ }^{16}$ A statistical cohort is not quite the same as a "synthetic" cohort since the latter is derived from a crosssection. The statistical cohort follows an actual birth cohort but draws a different (random) sample from that cohort each year.
} 
For each cohort I calculate the average number of years of high school enrollment experienced between ages 13 and 20. A time series of this statistic for males is displayed as the top line in the top panel of Figure 4. The shaded bars indicate the cohorts that experienced a change in the minimum wage while of high school age. In an appendix I give an example based on the Nixon round of minimum wage increases to illustrate how the affected cohorts were determined. In that episode the cohort born in 1959 experienced all three minimum wage increases of the Nixon round before they reached 17. That cohort was 17-years old in 1976 and is indicated that way in the Figure. That cohort also reported more years of high school enrollment (3.78 years) than the 1957 and 1958 birth cohorts (3.68 and 3.69 years respectively).

The three other rounds of minimum wage increases appear to have produced a similar ratcheting up in school attendance. All four episodes coincide with a noticeable increase in the average amount of high school experienced. ${ }^{17}$ Moreover, much of the gain from each episode persisted. According to my argument this effect can be attributed to the educational cascade caused by peer emulation. Indeed, the entire upward trend in male high school attachment during the period since 1972 can plausibly be attributed to minimum wage increases. ${ }^{18}$ We can illustrate this by removing the gains observed for the treated cohorts and then splice together the changes that remain. This is illustrated

\footnotetext{
${ }^{17}$ For the Carter four-step round the four cohorts born 1961-1964 were the most affected. The cohort of 1961 experienced two Carter steps between age 16 and 18. Those in the cohort of 1962 experienced three steps between age 15 and 18. The cohort of 1963 experienced all four steps during their high school years. Those from the cohort of 1964 experienced the last three Carter steps between age 14 and 17. The Bush I round had two steps. The cohorts of 1973 and 1974 experienced both of those changes between ages 15 and 18. The Clinton round also had two steps, but the first step took place on 1 October 1996 only a few days before the October CPS survey of that year. I take the cohorts of 1980 and 1981 as those that were most affected. Considering the simultaneity of the first step and the October survey, the cohort of 1979 experienced only one upward tick and that was between age 17 and 18. The cohort of 1982 witnessed the first step between age 13 and 14 and the second between 14 and 15 .

${ }^{18}$ Of course, there were several profound shifts in the labor market for those with less educational attainment beginning in the mid-1970s. Of particular importance was the increasing wage gap between those with a high school diploma and those without. It has been suggested that this would explain the upward drift in the average number of years of schooling in the period under study. What I am suggesting is that whatever impact the changing returns to schooling had they were primarily manifested during the rounds of minimum wage increases.
} 
diagrammatically by constructing the lower time trend in the upper panel of the figure. Remarkably, that line shows a downward trend.

As the lower panel of Figure 4 illustrates, the pattern for women is much the same as that for men. Women also reported increases in attendance at all four rounds. The magnitude of the increase for the Nixon round is less dramatic compared with that for men, but the magnitudes are roughly the same for the following three rounds. ${ }^{19}$ An exercise that deletes the periods of minimum wage exposure and splices the remaining years together for women is also presented in the figure. This demonstrates that the upward drift in high school exposure for women since the mid-1970s can be eliminated by removing the ratcheting influence of the cohorts treated by the minimum wage.

\section{Testing for the Impact of State Minimum Wage Increases, 1968-2003}

One objection to the foregoing analysis is that a number of the states had set minimum wages higher than the federal rate during this period. In those states the relevant rate is the state minimum, not the federal. Moreover, the changes in these state minimums often took place at different dates than the federal changes. I will deal with this concern in two ways. First, I compute the time series on the number of years of high school experienced by each cohort including only states in which the federal law dominated. I compare that series with that for all states which I displayed in Figure 4. This exercise is performed separately for each of the four post-1969 rounds since the states included in the first series changes as both federal and state laws are revised. The second test examines the schooling enrollments for a selection of states that set minimums at a higher level than the federal government and which changed their minimums on dates that differed from the federal changes. Among this set of state demonstrations it is possible to compare the state change(s) under examination with the experience of states that had no changes in either federal or state law.

\footnotetext{
${ }^{19}$ Interestingly, during the Nixon era the graduation rates for women and men measured at age 20 were roughly equal, but following 1975 female graduation rates were consistently higher than that for men. 
The first approach calculates the number of years of high school enrollment experienced by each cohort only for states that did not exceed the federal standard. An unpublished Data Appendix available from the author and also on line indicates the states that were included in each of the four tests. ${ }^{20}$ Figure 5 present the results for men. In two of the cases examined, the Nixon round and the Bush I round, the results are clearly stronger than in the original. In the Carter round the result is somewhat weaker than measured without excluding any states, but is still quite substantial. During the Clinton round the expansion of high school experience is measured at approximately the same magnitude.

As illustrated in Figure 3 there have been five episodes since 1950 when a significant number of states raised the minimum wage above the federal level. These five episodes preceded five rounds of increases legislated by Congress beginning with the Nixon round of 1974-1976. It would seem at first that this implies that there should be many cases that could be examined individually. However, due to limitations of the CPS data a number of the potential cases cannot be examined. The last cohort we can observe fully at the time writing was born in 1986 and was 20 in 2006, the last year for which the CPS data is presently available. That cutoff date, a year before the Bush II round, makes the examination of that episode premature. We are constrained when considering the first episode of state increases as well. For the years 1968-1973, the variable indicating the state of residence is aggregated in the public-use data source into regional groupings for most states. Of the 12 states that raised their minimum above the federal level prior to the Nixon round, only four, Connecticut, New York, New Jersey, and Illinois, can be individually examined. Only one additional state, California, is individually identified during the years prior to the Carter Four Step round of increases.

\footnotetext{
${ }^{20}$ The appendix mentioned can be found at this URL: \{I will supply this information in page proof $\}$. For the Nixon Round test some states were excluded because of the aggregated geocoding in the CPS files for 1968-1976. 
An additional limitation is produced by the annual nature of the CPS surveys, conducted in October of each year. Some states raised their rates less than a year before the subsequent change in the federal minimum. Illinois, for example, raised its rate in January 1974 only a few months before the federal increase in May of that year. Thus in our annual data source, Illinois' change would appear coincident with the federal change. That leaves only three states for our pre-Nixon test: New York, which changed its law in July 1970; Connecticut, October 1971; ${ }^{21}$ and New Jersey, October 1972.

The left-hand panel of Figure 6 graphically displays the minimum wage history of these three states for the 1970's. The lower line in each case is the federal minimum; the upper line displays the state's minimum wage when it exceeds the federal rate. The shading indicates the periods when the state minimum exceeded the federal. Note that the vertical scale is logarithmic and measures the wage rates in nominal dollars. The right-hand panel of Figure 6 presents the results for these three states taken together and compares them with the results for a selection of states where federal law dominates. ${ }^{22}$ As anticipated, the three-state aggregate displays a prominent spike in high school attendance before the Nixon round. And that spike was larger than the reaction to the Nixon round in those states. This makes sense, of course, since the impact of the May 1974 federal increase was muted in those states. ${ }^{23}$

Four states raised their rates above the federal level prior to the Carter round initiated in 1978. Two of those were New York and New Jersey. The other two were

\footnotetext{
${ }^{21}$ Connecticut officially raised its minimum allowable rate above the federal level in May 1971 but it was only by a symbolic one cent. In October the state raised its minimum to 25 cents above the federal level of $\$ 1.60$.

${ }^{22}$ I have aggregated the three states because of the low number of observations in Connecticut and New Jersey.

${ }^{23}$ We might also note that these three states were all states that experienced high enrollment rates compared with the rest of the county making proportional increases in the enrollment rate less likely.
} 
California and Hawai'i. None of the four can be separately analyzed. ${ }^{24}$ The best episode of the four for testing the impact of state increases is the period of the late 1980s. Eleven states raised their rates above the federal level. However, the last of the 11, Iowa, timed the effective date of its increase only four months before the federal change. Three others, Wisconsin, North Dakota, and Oregon, raised rates less than a year before the first increase of the Bush I round. The remaining seven can be divided into three distinct groups, Maine, Vermont, and Rhode Island increased their standards between October 1984 and October 1986. Hawai'i and California moved between October 1987 and October 1988. Those two were followed by Washington and Pennsylvania, both increasing their minimum rates on January 1989. In each case an upward shift in enrollment is recorded by the CPS and in each case it was substantially larger than the movement shown for the states that did not raise their minimums above the federal level.

\section{Pre-1972 Tests for Impact of Changes in the Federal Minimum Wage Law}

The micro-level CPS data used for the post-1971 tests is unavailable before 1968. Thus I need to switch data sets and adopt a different approach to study the impacts of changes in the federal minimum wage during this earlier period. ${ }^{25}$ Rather than surveying each cohort annually as they progress through the U.S. school system, I turn to retrospective reports of educational attainment. For this information I use the 1-percent samples drawn from the 1980, 1970, and 1960 decennial censuses available from the University of Minnesota's IPUMS project [Ruggles et al 2008]. ${ }^{26}$ Each individual was asked to report

\footnotetext{
${ }^{24}$ Unfortunately, Hawaii's data can not be separated from the data for Washington and Alaska. New Jersey's pre-Carter increase was in January 1975 during the middle of the Nixon round. New York and California's increases in October and November 1976 came directly between the Nixon round (May 1974January 1976) and the Carter Four Step (January 1978-January 1981). Thus California and New York experienced an increase every single year from 1974 to 1981 . For New Jersey and the states that did not exceed the federal standard there were also changes every year with the exception of 1977. Thus it would be difficult to discern a distinctly different pattern for these three states.

${ }^{25}$ There were few states with minimum wage increases that exceeded the federal minimum before 1970. See Figure 3.

${ }^{26}$ I cannot use the 1990 or subsequent census samples because they define educational attainment differently than the earlier censuses. In particular they consider the Generalized Educational Development (GED) degree (or high-school equivalency diploma) to be equivalent to graduating from twelfth grade and
} 
to the Census Bureau the highest grade of school ever attended. The micro-level data files report the highest grade of school completed and also identify respondents who began but did not finish the grade. From these reports I can calculate the number of years of high school attended by each respondent. Constraining attention to native-born individuals greater than 20 years old and less than 66 at each census, I was able to produce the cohort data displayed in Figure $7 .^{27}$ The line at the right, reproduces the CPS data for males shown earlier in Figure 4. Another line covering 1935 to 1975 presents the data for males constructed from the responses to the 1980 census for the high school cohorts of 1938 to 1976 . A third line is constructed from the 1970 census and the fourth line, pushing the series back to the high school class of 1918, is based on responses to the 1960 census.

Two things are obvious from this graph. First, there was a very rapid rise in high school attendance between 1918 and 1968 (from 1.47 years at the earlier date to 3.73 years at the later date) which was followed by the relatively slower growth evident after 1968. The dramatic educational advance associated with the spread of the high school after World War I is well known and it suggests that a long-run secular process was at work [Goldin and Katz 2008: Chapter 1]. The other point that the plot illustrates is that as each cohort aged from one census to the next its members seem to have reported more high school experience than they did at the previous census. Some of this upward drift of the trend line measured at different census dates might be due to selective mortality. At least, we might suppose that the better educated are healthier and live longer than lesseducated members of their cohort. But surely most of this educational attainment inflation is caused by selective memory (not to say prevarication) as one is further removed from one's high school days. For this reason we tend to favor the census reports from the respondents when they were younger.

earning a high school diploma. For a discussion of the problems this change created see Heckman, LaFontaine, and Rodriguez [2008].

${ }^{27}$ The foreign born are excluded because I cannot know whether they attended high school in the United States or a foreign country. When examining the CPS data this was not a concern since we were examining residents of the U.S. attending school (or not) in October of each year. 
In this analysis I focus on the minimum wage increases between 1950 and 1968. Because of the sharp upward gradient of the lines in Figure 7, it is clear that there is more influencing high school attendance than the increases in the minimum wage. To better highlight the impact of the minimum wage changes, I have removed the trend from the data and analyzed the residuals from the trend. ${ }^{28}$ I focused on the data from the census sample immediately following each increase. I examined four rounds of federal minimum wage increases between 1947 and 1974. ${ }^{29}$ As before, I labeled them with the name of the President who signed the bill.

Truman Increase - 1950

Enacted: October 1949

25 January 1950 from $\$ 0.40$ to $\$ 0.75$

Eisenhower Increase - 1956

1 March 1956 from $\$ 0.75$ to $\$ 1.00$

Kennedy Round - 1961-1963

3 September 1961 from $\$ 1.00$ to $\$ 1.15$

3 September 1963 to $\$ 1.25$

Enacted: August 1955

Enacted: May 1961

Johnson Round - 1967-1968

1 February 1967 from $\$ 1.25$ to $\$ 1.40$

1 February 1968 to $\$ 1.60$

For the Truman, Eisenhower, and Kennedy treatments the residuals from trend show a marked increase above the trend, supporting the hypothesis of a positive impact of these changes on school attendance. The Johnson round is less clear. If the treated cohorts were thought to be 1967-1970, rather than 1968-1971, then the fit would be better. I could rationalize that by noting that the Johnson bill was signed in September 1966 so it might be that the cohort that was 17 (largely seniors) in 1967 knew that the increase was

\footnotetext{
${ }^{28}$ The trends were estimated separately for each IPUMS sample. They are piecewise linear and pass through the observations for 1951, 1957, 1962, and 1974. These dates were chosen to coincide with the first cohort to experience one of the minimum wage increases while 14- to 16-years old. However, 1968 was skipped since the profile from the 1980 IPUMS indicated there was no upward trend between 1963 and 1974.

${ }^{29}$ See Table 1. For a discussion of the political and legislative history of these episodes see Waltman [2000: 34-41]. For the dates of enactment and other details see Stark [1949], "Eisenhower Signs" [1955], "Kennedy Signs" [1961], and Frankel [1966]. 
coming. However, I also should note that there was a significant break in the trends rates displayed in Figure 7 sometime in the mid-1960s and the results are sensitive to the way in which I have modeled the trend.

I can approximate the magnitude of the educational cascade induced by changes in the minimum wage between 1950 and 1972 by sequentially subtracting the estimated residuals from the IPUMS series on the number of years of high school attended. This is done at the left side of Figure 8. The line at the top is the original data based on the 1980 IPUMS and the lower line indicates what the trend might have been had there been no minimum wage changes. At the right-hand side of the figure the actual and the counterfactual series are extended to 2003 using the CPS data illustrated in Figure 4. If our approximations to the magnitude of the minimum-wage ratchet is accepted, then the average number of years of high school enrollment would have risen to only 3.52 years, rather than 3.73 years, for men born in 1951 (17 in 1968). Thereafter enrollment rates would have trended down to about 3.2 years for the cohort born in 1986 (17 in 2003), rather than slowly rising to around 3.9 years. This is an astonishing result. The cumulative effect of the minimum wage increases beginning in 1950 was to add 0.7 years to the average high school experience of men born in 1986.

\section{Conclusion}

Gavin Wright has suggested that the productivity slowdown that began after 1968 was associated with the rise of "flexible labor markets" and the dismantling of high-wage labor market institutions that prevailed in the preceding half century [Wright 2006: 152153]. The erosion of the real minimum wage after 1968 (displayed in Figure 1) was, according to Wright, a consequence of this labor market "regime change" from one complex of polices to another. Frank Levy and Peter Temin in this volume characterize the labor-market policies associated with the high-wage regime "the Treaty of Detroit" and the flexible labor market policies which followed "the Washington Consensus" [Levy and Temin 2010: 24-25 in ms]. One element of the Washington Consensus was the desirability (or acceptability) of low minimum wages [pp. 10, 20, and 25 in ms]. The 
downward trend of the counterfactual enrollment I have illustrated in Figure 8 is consistent with the view that a regime change took place and that labor market policy is relevant for long-run economic performance, just as Rosenbloom and Sundstrom argue in this volume [2010].

Why the regime change? Levy and Temin argue that policy makers, "unable to comprehend the macroeconomic causes of distress" (high unemployment, inflation, economic inefficiency), turned to microeconomic tinkering, dissolving the long-standing understandings embodied in "the Treaty of Detroit" [p. 25 in ms]. They might have been influenced by that old argument of George Stigler [1946] and the campaign led by Milton Friedman that the minimum wage made the unemployment problem (particularly the teenage unemployment problem) intractable. If so, I might add that the policy makers responsible were also lacking in microeconomic understanding. As Card and Krueger make clear, Stigler and Friedman were wrong. Their microeconomic theory was too simplified and was inconsistent with the macroeconomics of causes of unemployment [Card and Kruger 1995: Chapter 11].

The main contribution of this essay, as I see it, is to demonstrate the plausibility of the argument that increases in the minimum wage would increase the amount of schooling attained by a cohort that experiences the increases while in high school. If my empirical estimates are near correct, ${ }^{30}$ the impact is numerically significant and likely to be economically important. This is not to say that the manipulation of the minimum wage is the most effective, efficient, or fair policy to achieve an increase in high school attendance. But, further increases in the minimum wage large enough to counteract the

\footnotetext{
${ }^{30}$ Of course, my measure of the impact of the educational cascade induced by increases in the minimum wage is only approximate since it is based on several strong assumptions. My procedures for controlling for the underlying trend in the pre-1972 data and the assumption that there are no omitted variables that would influence the results are the most obvious issues. On the other hand, my own hunch is that my preliminary results are likely to underestimate the full effect. High on any list of omitted variables to add are controls for state differences in compulsory education laws and a variable to measure the impact of unemployment rates on the decision to remain in school. Omission of these variables is likely to attenuate the effect I am trying to assess.
} 
decline in the real value of the minimum wage are likely to be beneficial and (Republicans willing) likely to be politically achievable.

High school dropout rates remain unacceptably high, particularly for minority teenagers. A reconsideration of the impact of the minimum age would be a welcome component of any reorientation of government policy that attempts to deal with our current economic distress (high unemployment, deteriorating educational attainment). 


\section{Appendix: Specifying the Affected Cohorts: The Nixon Round}

The Nixon round consisted of three increases in the minimum wage; the first on 1 May 1974, the second on 1 January 1975, and the third on 1 January 1976. Note first that the typical ages of high school attendees in October was 14 to 17, though a significant fraction of 18-year olds (21.3 percent) were also still in high school. The Appendix table gives the birth cohort for each age class, 13 through 20, beginning with the October survey taken before the first rate change (and before President Nixon signed the wage bill $^{31}$ ) continuing through the October that followed the third increase. I consider the cohorts of 1958 and 1959 to be the most directly affected by the Nixon round. The cohort born in 1957 aged from 16 to 17 years over the year that the first minimum wage change took place. But most 17-year olds would be seniors ( $12^{\text {th }}$ graders) in 1974, so this cohort had only a brush with the Nixon round. The 1958 cohort on the other hand experienced both the first and second increases before they reached 17. The 1959 cohort experienced all three boosts in the minimum during their high school years. ${ }^{32}$

I would expect the 1959 cohort to experience more years of high school education than either the 1957 or 1958 cohorts. This is, indeed, what we find. The 1959 cohort (they were 17 in 1976) reported 3.78 years. The 1958 cohort logged on average 3.69 years of high school enrollment by the time they were 20. The 1957 cohort reported 3.68 years.

\footnotetext{
${ }^{31}$ President Nixon had vetoed the bill the previous September and his change of heart was somewhat of a surprise. "But politicians in both parties suggested that, with possible impeachment hanging over his head, Mr. Nixon could not afford to risk a second veto" [Apple 1974].

${ }^{32}$ Recall that the 1958 birth cohort is calculated by subtracting the age of the respondent in October from the year that the survey was conducted. Thus the two cohorts of 1958-1959 consist of those born between 15 October 1957 and 14 October 1959. 


\section{References}

Adams, F. Gerard, “The Macroeconomic Impacts of Increasing the Minimum Wage," Journal of Policy Modeling 11(2) Summer 1989: 179-189.

Apple, Jr.; R. W. “President Signs Rise in Pay Base to \$2.30an Hour; He Cites 'Reservations' But Says Higher Minimum Can 'No Longer Be Delayed;' Bill Vetoed Last Fall; Increases in Stages Are Extended to 7 Million: Many More Covered; Series of Steps-Ups: Rules on Domestics," New York Times, April 9, 1974.

Brown, Charles, “Minimum Wage Laws: Are They Overrated?” Journal of Economic Perspectives 2(3) Summer 1988: 133-145.

Brown, Charles, "Minimum Wages, Employment, and the Distribution of Income," in Orley Ashenfelter and David Card, editors, Handbook of Labor Economics, Volume 3B, Elsevier, 1999: 2101-2163.

Brown, Charles; Curtis Gilroy; and Andrew Kohen, "The Effect of The Minimum Wage on Employment and Unemployment," Journal of Economic Literature 20(2) June 1982: 487-528.

Card, David, and Alan B. Krueger, Myth and Measurement: The New Economics of the Minimum Wage, Princeton University Press, 1995.

Card, David, and Thomas Lemieux, "Dropout and Enrollment Trends in the Post-War Period: What Went Wrong in the 1970s?" National Bureau of Economic Research Working Paper, Number 7658, April 2000.

“Carter Signs Minimum Wage Bill, Giving Raises of 45 Percent by '81,” New York Times, November 2, 1977.

Carter, Susan B; Scott Sigmund Gartner; Michael R. Haines; Alan L. Olmstead; Richard Sutch; and Gavin Wright; editors, Historical Statistics of the United States, Millennial Edition, Cambridge University Press, 2006.

Douglas, Paul H., and Joseph Hackman,” The Fair Labor Standards Act of 1938: II,” Political Science Quarterly 54(1) March 1939: 29-55.

"Eisenhower Signs \$1 Minimum Pay; Rise From 75 Cents an Hour Effective Next March 1 Will Affect 2,000,000," New York Times, August 13, 1955.

Frankel, Max, "President Signs Minimum Pay Bill; Hails Rise to \$1.60 in '68 - Recalls 25-Cent Wage Gained by New Deal, New York Times, September 24, 1966.

Freeman, Richard B., "Why Do So Many Young American Men Commit Crimes and What Might We Do About It?" Journal of Economic Perspectives 10(1) Winter 1996: 25-42.

Friedman, Milton, Bright Promises, Dismal Performance: An Economist's Protest, Harcourt Brace Jovanovich, 1983.

Fritsch, Conrad, "Exemptions from the Fair labor Standards Act, Retail Trade and Services," in Report of the Minimum Wage Study Commission, volume 5, The Commission, June 1981.

Richard Sutch

Minimum Wage Draft January 7, 2010

Page 24 of 38 
Goldin, Claudia, and Lawrence F. Katz, The Race between Education and Technology, Harvard University Press, 2008.

Haugen, Steven E., and Earl F. Mellor, "Estimating the Number of Minimum Wage Workers," Monthly Labor Review 113(1) January 1990: 70-74.

Heckman, James J.; Paul A. LaFontaine; and Pedro L. Rodriguez; "Taking the Easy Way Out: How the GED Testing Program Induces Students to Drop Out," National Bureau of Economic Research Working Paper Number 14044, May 2008.

Katz, Lawrence F., and Alan B. Krueger, "The Effects of the New Minimum Wage Law in a Low-Wage Labor Market," National Bureau of Economic Research Working Paper Number 3655, March 1991.

Katz, Lawrence F., and Alan B. Krueger, "The Effect of the Minimum Wage on the Fast-Food Industry," Industrial and Labor Relations Review 46(1) October 1992: 6-21.

Kelley, Florence, “Minimum-Wage Laws,” Journal of Political Economy 20(10) December 1912: 9991010.

“Kennedy Signs Wage-Floor Bill; 3.6 Million More Get Coverage,” New York Times, May 6, 1961.

Kilborn, Peter T., “A Minimal-Impact Minimum Wage,” New York Times, April 6, 1997.

Labaton, Stephen, “Congress Passes Increase in the Minimum Wage," New York Times, May 25, 2007.

Levy, Frank, and Peter Temin, "Inequality and Institutions in Twentieth Century America," Chapter 12 in Paul W. Rhode, Joshua L. Rosenbloom, and David Weiman, editors, Economic Evolution and Revolution in Historical Time, Stanford University Press, 2010: ???-???.

Mattila, J. Peter, "The Impact of Minimum Wages on Teenage Schooling and on Part-Time/Full-Time Employment of Youths," in Simon Rottenberg, editor, The Economics of Legal Minimum Wages, American Enterprise Institute, 1981: 61-87.

Meredith, Robyn, "Politics Aside, Economy Is Shrugging Off Rise to \$4.75," New York Times, October 1, 1996.

Moses, Montrose J., editor, The Fireside Chats of Franklin Delano Roosevelt [on line], Project Gutenberg, 2002.

Neumark, David, and William Wascher, "Minimum Wage Effects on Employment and School Enrollment," Journal of Business and Economic Statistics 13(2) April 1995: 199-206.

Neumark, David, and William Wascher, "Minimum-Wage Effects on School and Work Transitions of Teenagers," American Economic Review 85(2) May 1995: 244-249.

Neumark, David, and William Wascher, "Minimum Wages and Skill Acquisition: Another Look at Schooling Effects," Economics of Education Review 22(1) February 2003: 1-10. 
Nordlund, Willis J., The Quest for a Living Wage: The History of the Federal Minimum Wage Program, Greenwood Press, 1997.

Norman, Geoffrey, "Playboy Interview: Milton Friedman," Playboy 28(2), February 1973: 51-68 and 74. Reprinted in Milton Friedman, Bright Promises, Dismal Performance: An Economist's Protest, Harcourt Brace Jovanovich, 1983: 9-59.

Passell, Peter, “Minimum Wage: A Reality Test,” New York Times, March 15, 1989.

Ragan, Jr.; James F., "Minimum Wages and the Youth Labor Market," Review of Economics and Statistics 59(2) May 1977: 129-136.

Raskey, Susan F., “The Minimum-Wage Fight Isn't Really About Pay,” New York Times, May 7, 1989.

Roosevelt, Franklin D., "Speech before the 1936 Democratic National Convention," Philadelphia, Pennsylvania, June 27, 1936, in John T. Woolley and Gerhard Peters, editors, The American Presidency Project [online], University of California, Santa Barbara.

Rosenbaum, David E., "Bush and Congress Reach Accord Raising Minimum Wage to \$4.25," New York Times, November 1, 1989.

Rosenbloom, Joshua L., and William A. Sundstrom, "Labor-Market Regimes in U.S. Economic History," Chapter 11 in Paul W. Rhode, Joshua L. Rosenbloom, and David Weiman, editors, Economic Evolution and Revolution in Historical Time, Stanford University Press, 2010: ???-???.

Rottenberg, Simon, editor, The Economics of Legal Minimum Wages, American Enterprise Institute, 1981.

Ruggles, Steven; Matthew Sobek; Trent Alexander; Catherine A. Fitch; Ronald Goeken; Patricia Kelly Hall; Miriam King; and Chad Ronnander, Integrated Public Use Microdata Series: Version 4.0 [on line database], Minnesota Population Center, University of Minnesota, 2008.

Schmitt, Eric, "Bill to Increase Minimum Pay Clears Hurdle In a New Deal," New York Times, August 1, 1996.

Shapiro, Fred R., The Yale Book of Quotations, Yale University Press, 2006.

Solon, Gary, "The Minimum Wage and Teenage Employment: The Role of Serial Correlation and Seasonality." Journal of Human Resources 20(2) Spring 1985: 292-297.

Stark, Louis, "Minimum Pay Bill is Sent to Truman; Wage Floor is Set at 75 Cents but Coverage is Reduced by Final Compromise," New York Times, October 19, 1949.

Stevenson, Richard W., "Clinton Signs a Bill Raising Minimum Wage by 90 Cents," New York Times, August 21, 1996.

Stigler, George J., "The Economics of Minimum Wage Legislation,” American Economic Review 36(3) June 1946: 358-365.

U. S. Bureau of Labor Statistics, Consumer Price Index [on line database].

Richard Sutch

Minimum Wage Draft January 7, 2010

Page 26 of 38 
U.S. Bureau of Labor Statistics, “Characteristics of Minimum Wage Workers: 2005” [online], May 2006.

U.S. Department of Labor, Bureau of Labor Standards, Growth of Labor Law in the United States, Second edition, U.S. Superintendent of Documents, 1967.

U.S. Department of Labor, Employment Standards Administration, "Federal Minimum Wage Rates under the Fair Labor Standards Act," [on line].

U.S. Department of Labor, Employment Standards Administration, Wage and Hours Division, Minimum Wage Laws in the States: January 1, 2008 [on line], December 2007.

U.S. Department of Labor, Employment Standards Administration, "History of Changes to the Minimum Wage Law," [on line].

U.S. Department of Labor, Employment Standards Administration, Wage and Hours Division, "History of Federal Minimum Wage Rates Under the Fair Labor Standards Act, 1938 - 2007” [on line].

Uchitelle, Louis, “A Pay Raise's Impact,” New York Times, January 12, 1995.

Uchitelle, Louis, “Employers Shun Sub-Minimum Wage,” New York Times, December 31, 1990.

Unicon Research, CPS Utilities: Education and School Enrollment, October 1968-2005, DVD version 5.5, December 6, 2007.

Waltman, Jerold, The Politics of the Minimum Wage, University of Illinois Press, 2000.

Webb, Sidney, “The Economic Theory of a Legal Minimum Wage," Journal of Political Economy 20(10) December 1912: 973-998.

Wellington, Alison, "Effects of the Minimum Wage on the Employment Status of Youths: An Update." Journal of Human Resources 26(1) Winter 1991: 27-46.

Woolley, John T., and Gerhard Peters, editors, The American Presidency Project [on line], University of California, Santa Barbara.

Wright, Gavin, Old South, New South: Revolutions in the Southern Economy Since the Civil War, Basic Books, 1986.

Wright, Gavin, "Labor History and Labor Econmics," Chapter 7 in Alexander J. Field, editor, The Future of Economic History, Kluwer-Nijhoff, 1987: 313-348.

Wright, Gavin, "Productivity Growth and the American Labor Market: The 1990s in Historical Perspective," Chapter 7 in Paul W. Rhode and Gianni Toniolo, editors, The Global Economy in the 1990s: A Long-Run Perspective, Cambridge University Press, 2006: 139-160. 


\section{Table 1: Federal minimum wage rates under the Fair Labor Standards Act and amendments: 1938-2009}

\begin{tabular}{|c|c|c|c|c|c|c|c|}
\hline \multirow[b]{4}{*}{ Year } & \multirow[b]{4}{*}{ Month } & \multirow[b]{4}{*}{ Day } & \multirow{2}{*}{$\begin{array}{c}1938 \text { Fair } \\
\text { Labor } \\
\text { Standards Act }\end{array}$} & \multirow[b]{2}{*}{$\begin{array}{c}1961 \\
\text { amendments }\end{array}$} & \multicolumn{2}{|c|}{$\begin{array}{c}1966 \text { and subsequent } \\
\text { amendments }\end{array}$} & \multirow{2}{*}{$\begin{array}{c}1989 \text { and } \\
1996 \\
\text { amendments } \\
\begin{array}{c}\text { 90-day youth } \\
\text { subminimum }\end{array}\end{array}$} \\
\hline & & & & & $\begin{array}{l}\text { Nonfarm } \\
\text { workers }\end{array}$ & $\begin{array}{c}\begin{array}{c}\text { Farm } \\
\text { workers }\end{array} \\
\end{array}$ & \\
\hline & & & 1.1 & 1.2 & 1.3 & 1.4 & 1.5 \\
\hline & & & $\begin{array}{c}\text { Dollars per } \\
\text { hour }\end{array}$ & $\begin{array}{c}\text { Dollars per } \\
\text { hour }\end{array}$ & $\begin{array}{l}\text { Dollars } \\
\text { per hour }\end{array}$ & $\begin{array}{l}\text { Dollars } \\
\text { per hour }\end{array}$ & $\begin{array}{c}\text { Dollars per } \\
\text { hour }\end{array}$ \\
\hline 1938 & Oct & 24 & 0.25 & ---- & ---- & ---- & ---- \\
\hline 1939 & Oct & 24 & 0.30 & ---- & ---- & ---- & ---- \\
\hline 1945 & Oct & 24 & 0.40 & ---- & ---- & ---- & ---- \\
\hline 1950 & Jan & 25 & 0.75 & ---- & ---- & ---- & ---- \\
\hline 1956 & Mar & 1 & 1.00 & ---- & ---- & ---- & ---- \\
\hline 1961 & Sep & 3 & 1.15 & 1.00 & ---- & ---- & ---- \\
\hline 1963 & Sep & 3 & 1.25 & 1.00 & ---- & ---- & ---- \\
\hline 1964 & Sep & 3 & 1.25 & 1.15 & ---- & ---- & ---- \\
\hline 1965 & Sep & 3 & 1.25 & 1.25 & ---- & ---- & ---- \\
\hline 1967 & Feb & 1 & 1.40 & 1.40 & 1.00 & 1.00 & ---- \\
\hline 1968 & Feb & 1 & 1.60 & 1.60 & 1.15 & 1.15 & ---- \\
\hline 1969 & Feb & 1 & 1.60 & 1.60 & 1.30 & 1.30 & ---- \\
\hline 1970 & Feb & 1 & 1.60 & 1.60 & 1.45 & 1.30 & ---- \\
\hline 1971 & Feb & 1 & 1.60 & 1.60 & 1.60 & 1.30 & ---- \\
\hline 1974 & May & 1 & 2.00 & 2.00 & 1.90 & 1.60 & ---- \\
\hline 1975 & Jan & 1 & 2.10 & 2.10 & 2.00 & 1.80 & ---- \\
\hline 1976 & Jan & 1 & 2.30 & 2.30 & 2.20 & 2.00 & ---- \\
\hline 1977 & Jan & 1 & 2.30 & 2.30 & 2.30 & 2.20 & ---- \\
\hline 1978 & Jan & 1 & 2.65 & 2.65 & 2.65 & 2.65 & ---- \\
\hline 1979 & Jan & 1 & 2.90 & 2.90 & 2.90 & 2.90 & ---- \\
\hline 1980 & Jan & 1 & 3.10 & 3.10 & 3.10 & 3.10 & ---- \\
\hline 1981 & Jan & 1 & 3.35 & 3.35 & 3.35 & 3.35 & ---- \\
\hline 1990 & Apr & 1 & 3.80 & 3.80 & 3.80 & 3.80 & 3.35 \\
\hline 1991 & Apr & 1 & 4.25 & 4.25 & 4.25 & 4.25 & 3.61 \\
\hline 1993 & Apr & 1 & 4.25 & 4.25 & 4.25 & 4.25 & --- \\
\hline 1996 & Oct & 1 & 4.75 & 4.75 & 4.75 & 4.75 & 4.25 \\
\hline 1997 & Sep & 1 & 5.15 & 5.15 & 5.15 & 5.15 & 4.25 \\
\hline 2007 & July & 24 & 5.85 & 5.85 & 5.85 & 5.85 & 4.25 \\
\hline 2008 & July & 24 & 6.55 & 6.55 & 6.55 & 6.55 & 4.25 \\
\hline 2009 & July & 24 & 7.25 & 7.25 & 7.25 & 7.25 & 4.25 \\
\hline
\end{tabular}


Table 1: Federal minimum wage rates under the Fair Labor Standards Act and amendments: 1938-2009

This table revises and updates the table presented in Historical Statistics of the United States [Carter et al 2006: Table Ba4422-4425. The original table was contributed by Susan B. Carter

Sources

U.S. Department of Labor, Employment Standards Administration, "Federal Minimum Wage Rates under the Fair Labor Standards Act," http://www.dol.gov/esa/minwage/chart.htm

U.S. Department of Labor, Employment Standards Administration, "History of Changes to the Minimum Wage Law," http://www.dol.gov/esa/minwage/coverage.htm

\section{Documentation}

The federal minimum wage was established with the passage of the Fair Labor Standards Act (FLSA) of 1938. The FSLA was the capstone of the New Deal legislation designed to end the Great Depression of the 1930s. The 1938 Act applied to workers engaged in interstate commerce or in the production of goods for interstate commerce.

Series 1.1. Indicates the new minimum level at each successive change. All increases in the minimum wage rate beginning in 1978 covered all non-exempt workers.

Series 1.2. The 1961 amendments to the FLSA extended coverage to employees in large retail and service enterprises as well as to local transit, construction, and to gasoline service station employees. The level of the minimum for these workers is shown in this series. After January 30, 1968 the rate for these employees matched that for all covered, nonexempt workers under the 1938 Act. In 1990, the new law raised the annual dollar volume test for enterprise coverage. A grandfather clause was established to protect employees who no longer met the tests for individual coverage, whose employers were covered as of March 31, 1990, but who would have become exempt from coverage with the new volume test.

Series 1.3-1.4. The 1966 amendments to the FSLA extended coverage to state and local government employees of hospitals, nursing homes, and schools, and to laundries, dry cleaners, and large hotels, motels, restaurants, and farms. Subsequent amendments extended coverage to the remaining federal, state, and local government employees who were not protected in 1966, to certain workers in retail and service trades previously exempted, and to certain domestic workers in private household employment. After December 31, 1976 the minimum for non-farm workers covered by the 1966 amendments matched that for all covered, non-exempt workers under the 1938 Act. The minimum for farm workers matched that for all covered, nonexempt workers after December 31, 1977.

Series 1.5. Beginning April 1, 1990 a youth subminimum wage ("training wage") was established by the 1989 amendments at 85 percent of the statutory minimum wage (but not less than $\$ 3.35$ per hour) that applied to employees under 20 years of age during their first 90 continuous days of employment. This provision expired after March 31, 1993. Under the 1996 amendments a youth subminimum wage of $\$ 4.25$ per hour was established beginning October 1,996 that applied to employees under 20 years ofage during their first 90 consecutive calendar days of employment. The terms of the two youth subminimum wage plans were confirmed by newspaper accounts at the time. See David E. Rosenbaum, "Bush and Congress Reach Accord Raising Minimum Wage to \$4.25," New York Times, November 1, 1989, and Eric Schmitt, "Bill to Increase Minimum Pay Clears Hurdle In a New Deal," New York Times, August 1, 1996. 


\section{Appendix Table}

Example: the Nixon Round of Minimum Wage Increases: May 1974-January 1976

\begin{tabular}{|c|c|c|c|c|c|c|c|c|c|c|}
\hline & & & $\begin{array}{l}13- \\
\text { years }\end{array}$ & $\begin{array}{l}14- \\
\text { years }\end{array}$ & $\begin{array}{l}15- \\
\text { years }\end{array}$ & $\begin{array}{l}16- \\
\text { years }\end{array}$ & $\begin{array}{l}17- \\
\text { years }\end{array}$ & $\begin{array}{l}18- \\
\text { years }\end{array}$ & $\begin{array}{l}19- \\
\text { years }\end{array}$ & $\begin{array}{l}20- \\
\text { years }\end{array}$ \\
\hline \multicolumn{3}{|c|}{$\begin{array}{r}\text { Percent of Age Class Attending } \\
\text { High School - Average for Birth } \\
\text { Cohorts of 1957-1959 }\end{array}$} & 8.0 & 73.0 & 91.5 & 92.6 & 79.9 & 21.3 & 4.4 & 1.3 \\
\hline Month & Year & $\begin{array}{l}\text { Federal } \\
\text { Minimum } \\
\text { Wage }\end{array}$ & \multicolumn{8}{|c|}{ Year of Birth of Individual in October of Indicated Year } \\
\hline October & 1973 & $\$ 1.60$ & 1960 & 1959 & 1958 & 1957 & 1956 & 1955 & 1954 & 1953 \\
\hline May & 1974 & $\$ 2.00$ & & & & & & & & \\
\hline October & 1974 & $\$ 2.00$ & 1961 & 1960 & 1959 & 1958 & 1957 & 1956 & 1955 & 1954 \\
\hline January & 1975 & $\$ 2.10$ & & & & & & & & \\
\hline October & 1975 & $\$ 2.10$ & 1962 & 1961 & 1960 & 1959 & 1958 & 1957 & 1956 & 1955 \\
\hline January & 1976 & $\$ 2.30$ & & & & & & & & \\
\hline October & 1976 & $\$ 2.30$ & 1963 & 1962 & 1961 & 1960 & 1959 & 1958 & 1957 & 1956 \\
\hline
\end{tabular}


Figure 1: Federal Minimum Wage: Real Dollars per Hour

Source: Table 1 and U.S. Bureau of Labor Statistics, Consumer Price Index [on line].

\section{Federal Minimum Wage}

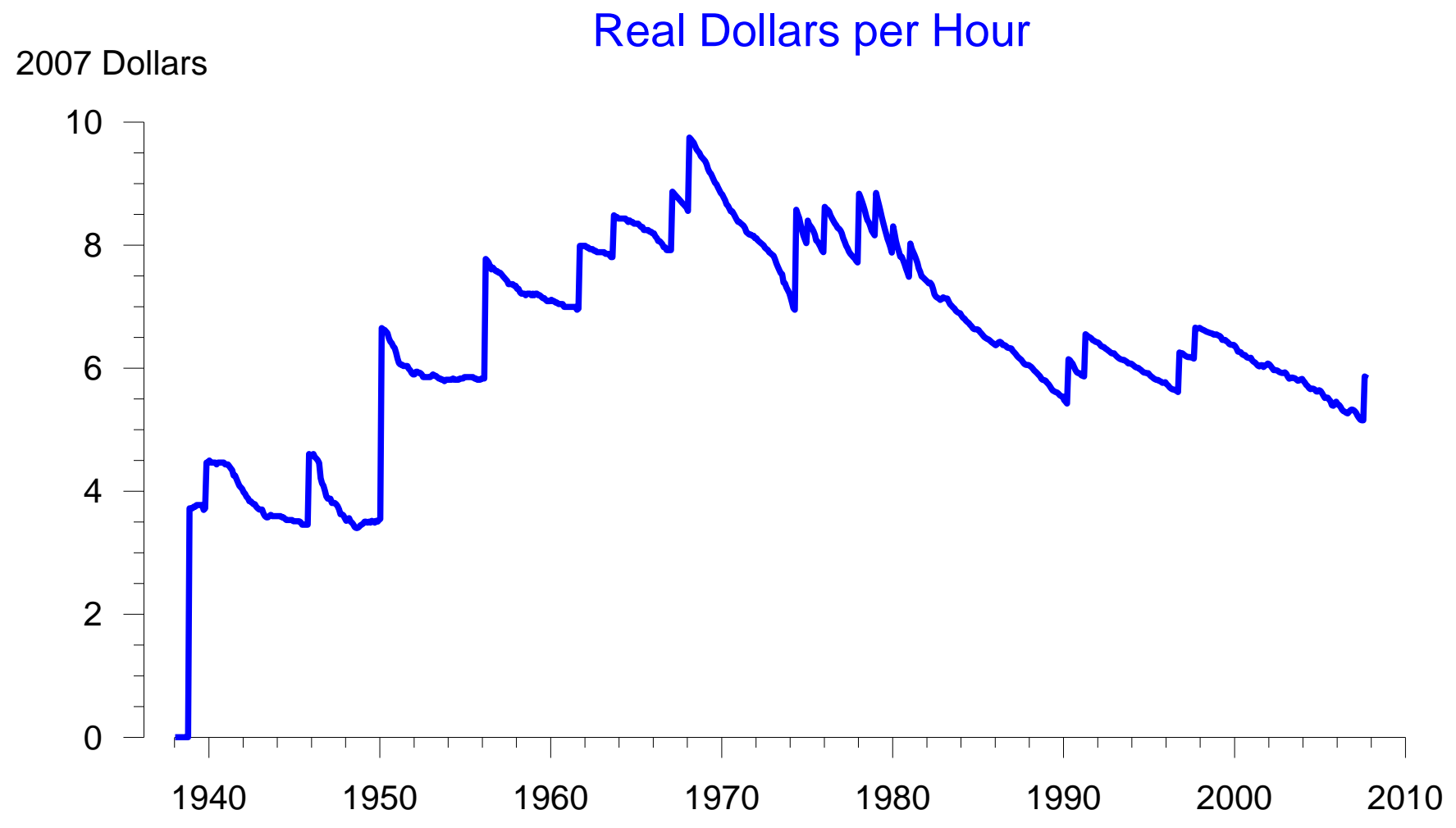


Figure 2: Skill Distribution of High School Students

\section{Skill Distribution of High School Students}

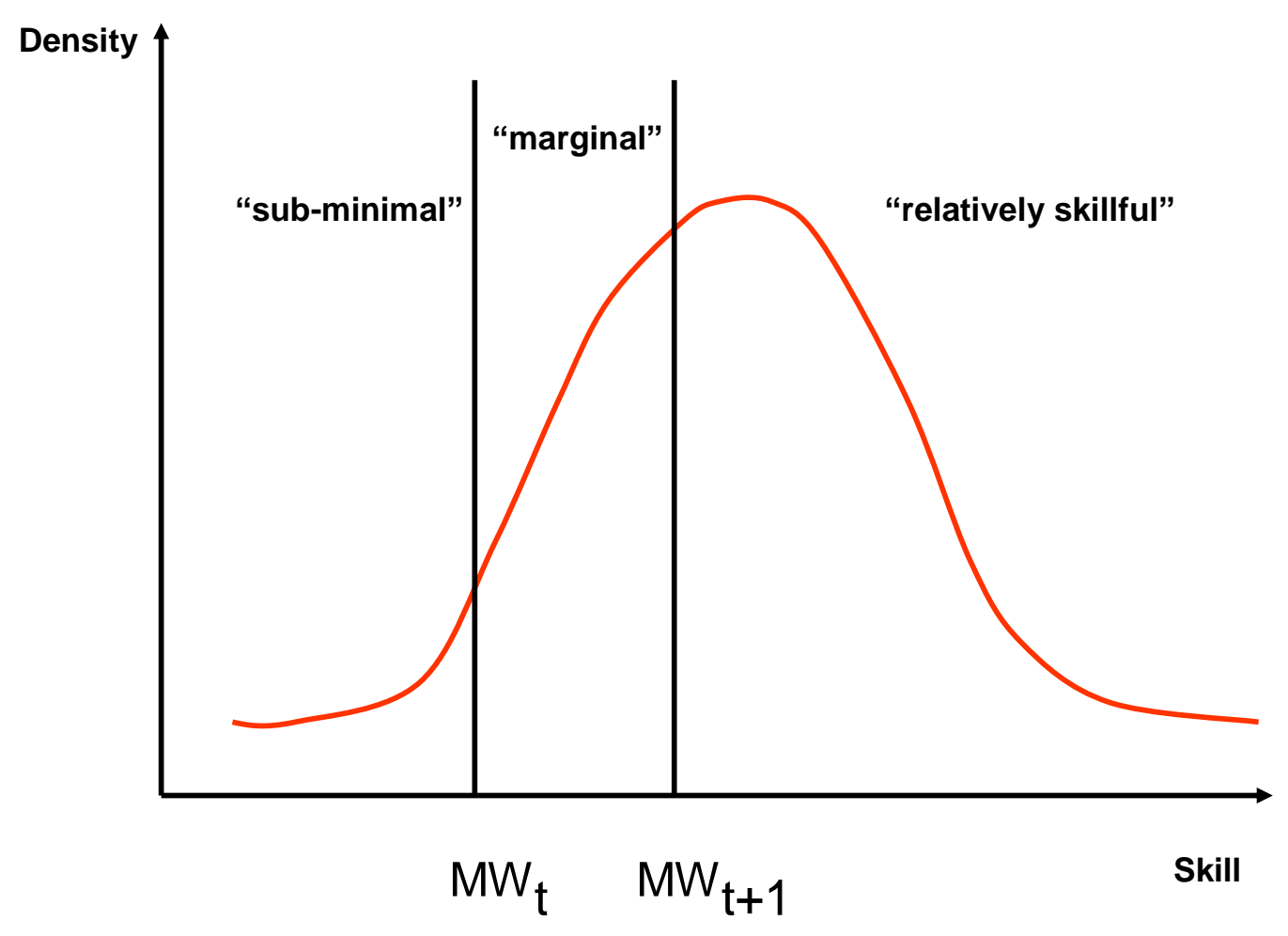

Skill and wages measured in real terms 
Figure 3: Number of States with a Minimum Wage Law

Source: Data Appendix available from the author and on line.

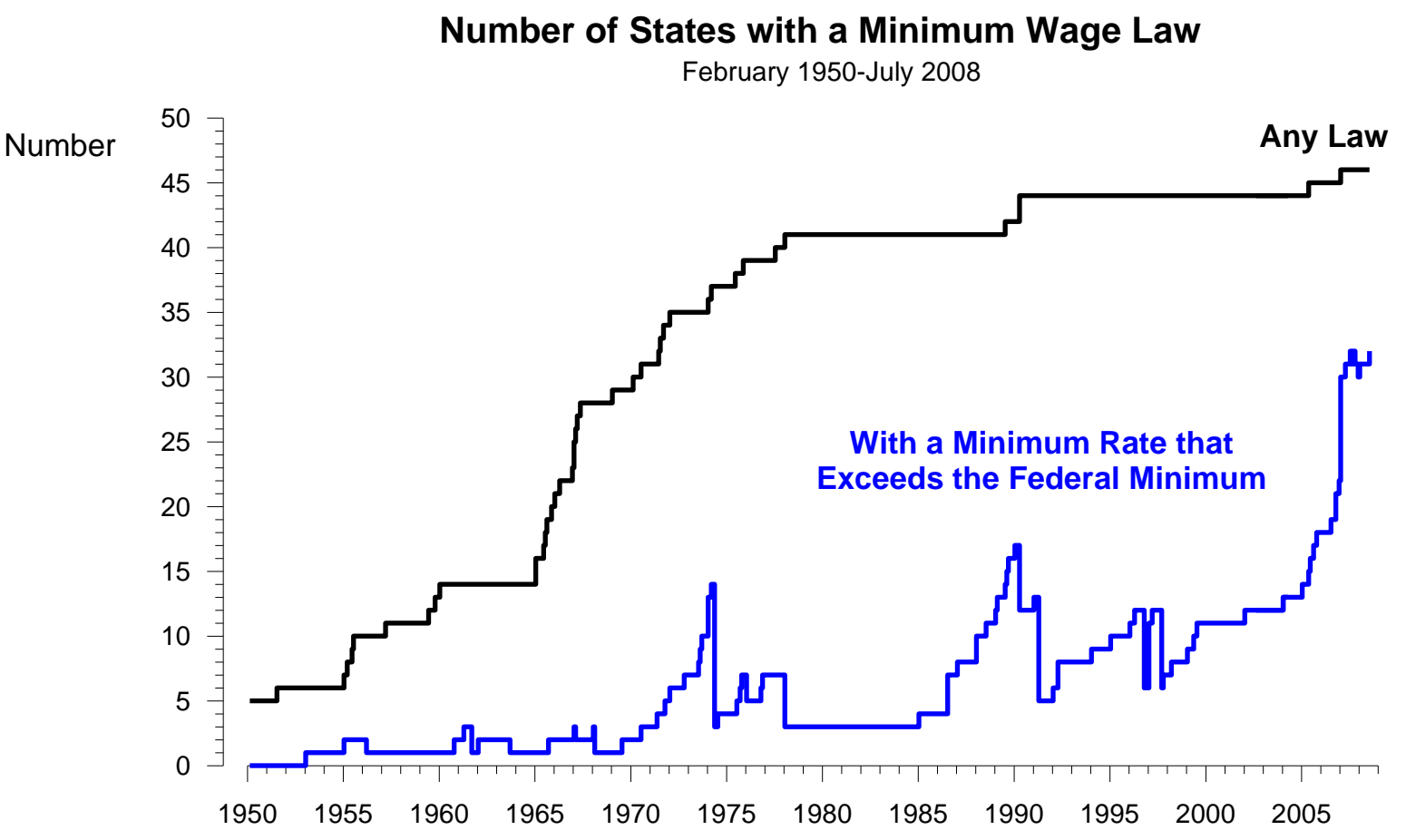


Figure 4: Number of Years of High School Enrollment

4a [top panel]: Males - October CPS

4b [bottom panel]: Females - October CPS

Source: Author's calculations based on Unicon, October CPS Utilities [2007]
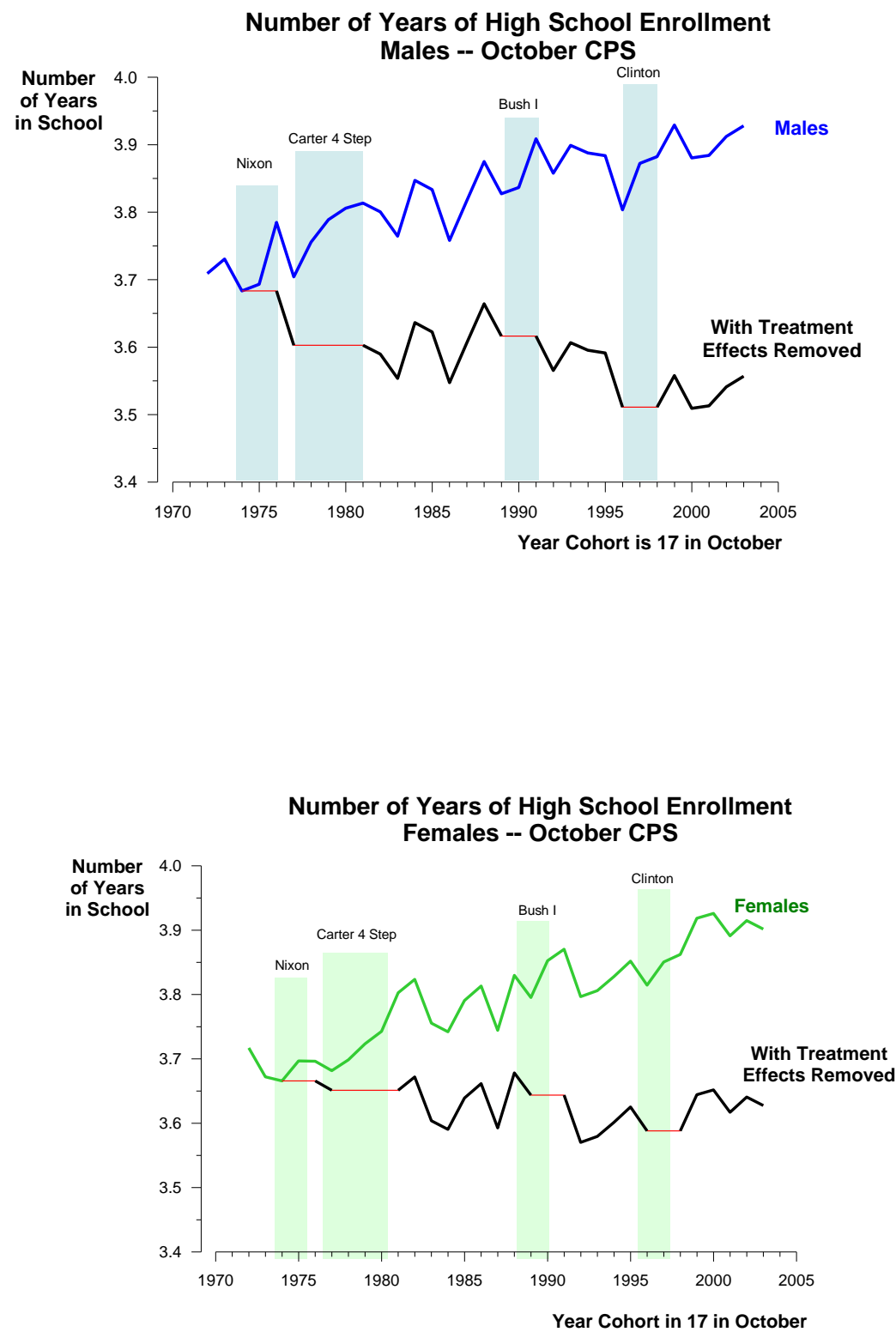
Figure 5: Results with States that Exceed the Federal Minimum Removed 5a [top panel]: Nixon Round and Carter Four Step

5 b [bottom panel]: Bush I Round and Clinton Round

\section{Results with States that Exceed the Federal Minimum Removed}

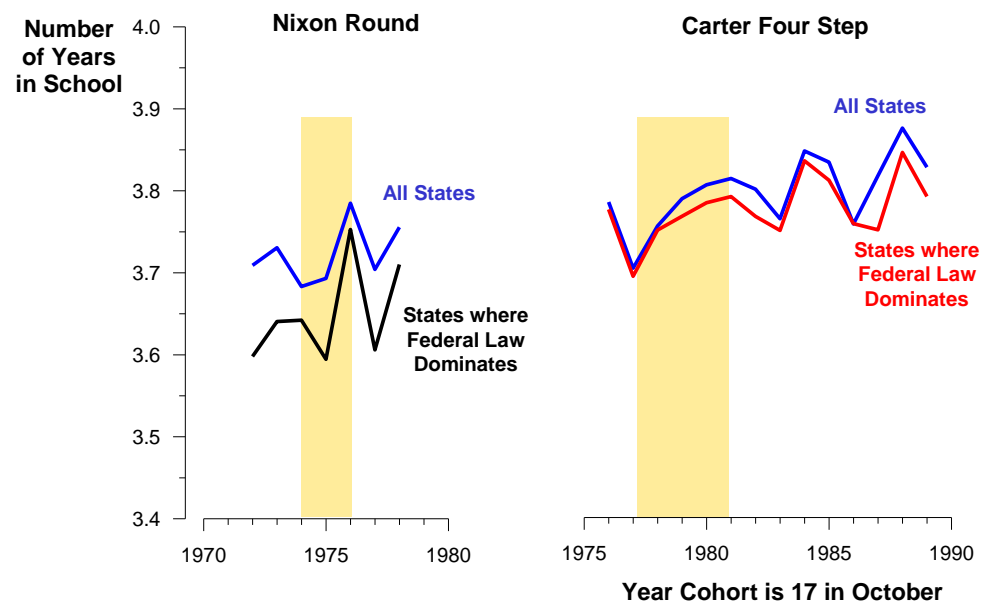

Results with States that Exceed the

Federal Minimum Removed

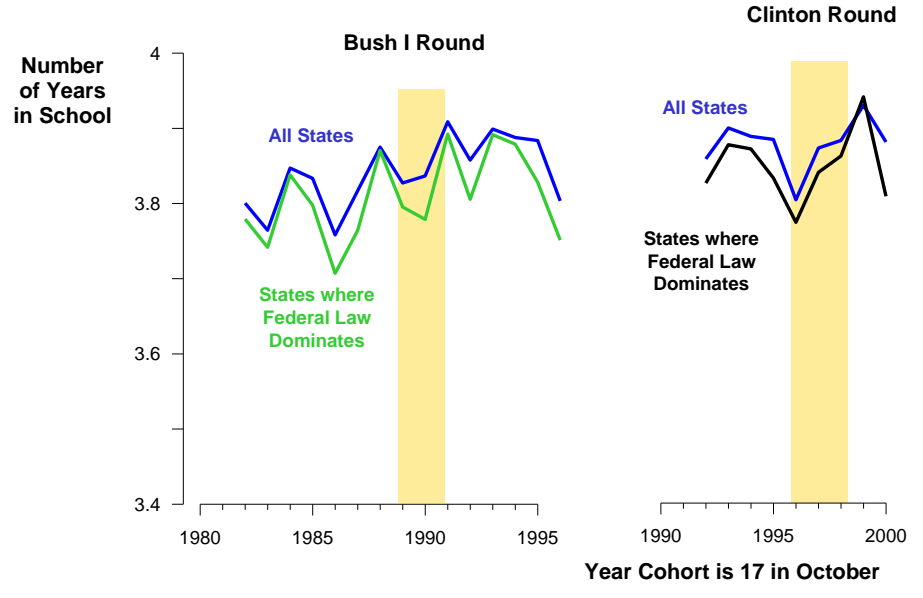


Figure 6: Three States that Exceeded the Federal Minimum in the Mid-1970s Source: Author's calculations. See text.
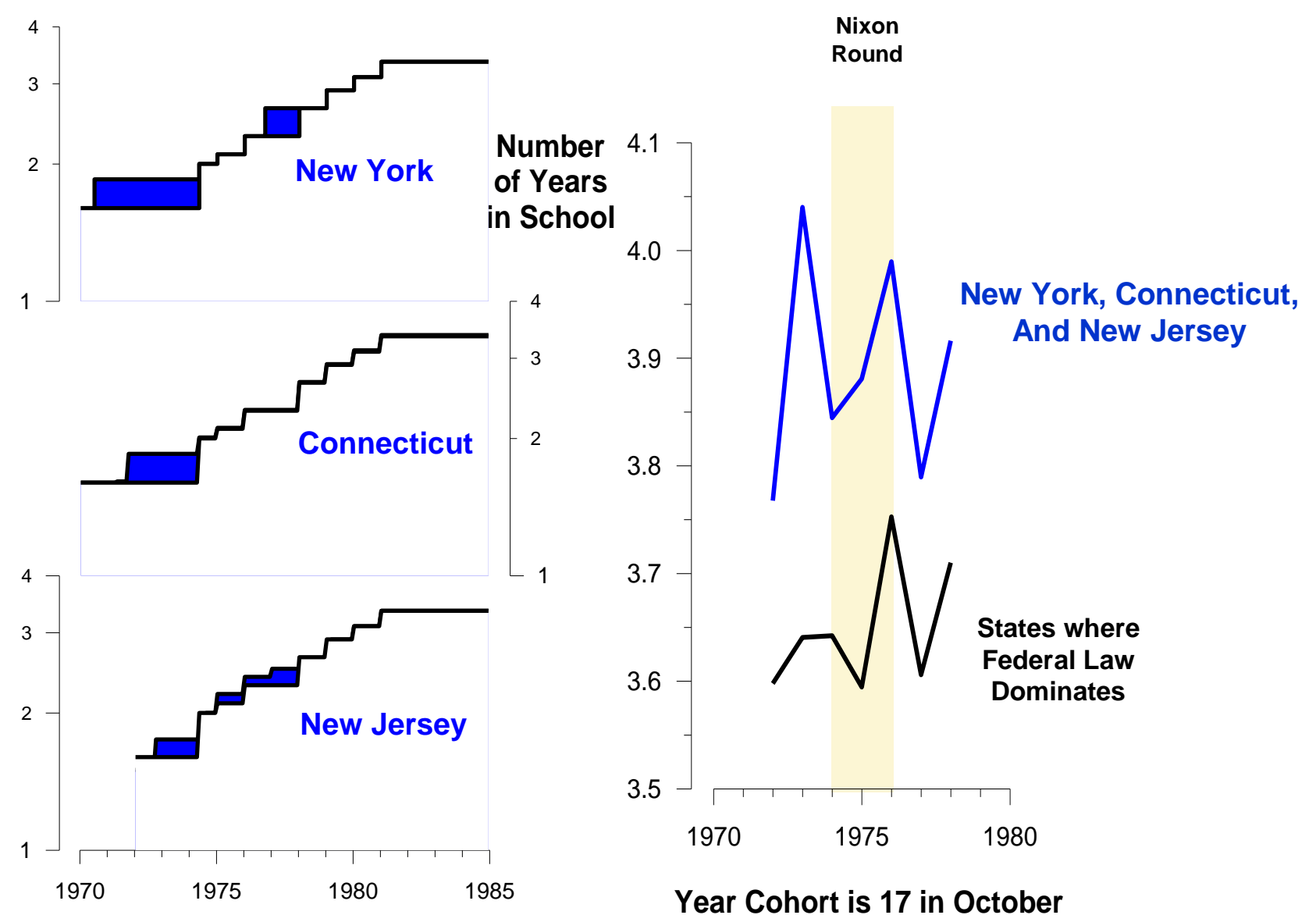
Figure 7: Number of Years of High School Enrollment: Males - Census Retrospective versus CPS Source: Author's calculations based on the IPUMS samples [Ruggles et al 2008] and the October CPS [Unicon 2007]. For the IPUMS samples the cohort is aged 17 in April. For the CPS sample the cohort is aged 17 in October.

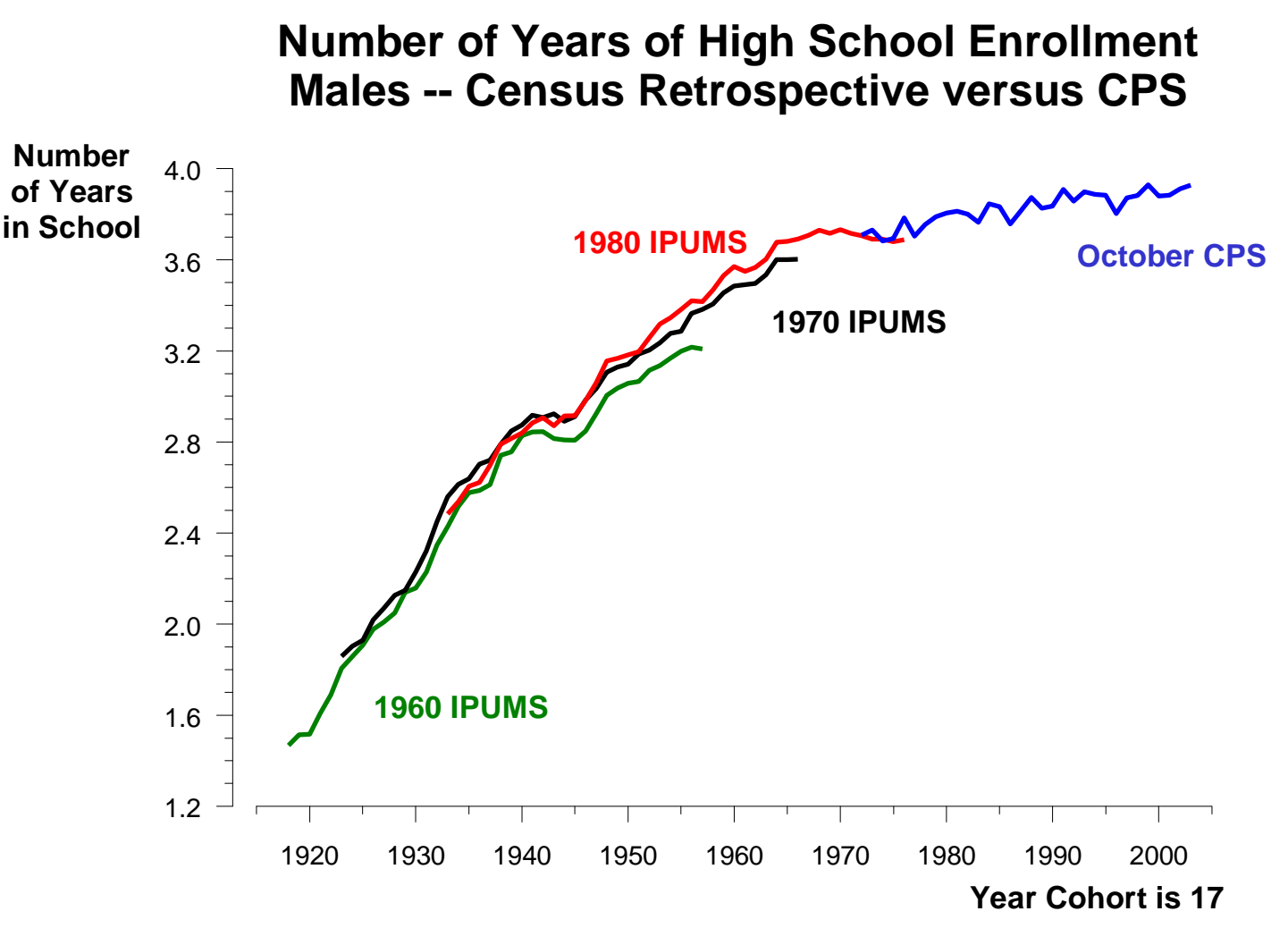


Figure 8: Number of Years of High School Enrolment, 1948-2003

Source: Author's calculations based on IPUMS and October CPS. See text.

\section{Number of Years of High School Enrollment}

Males

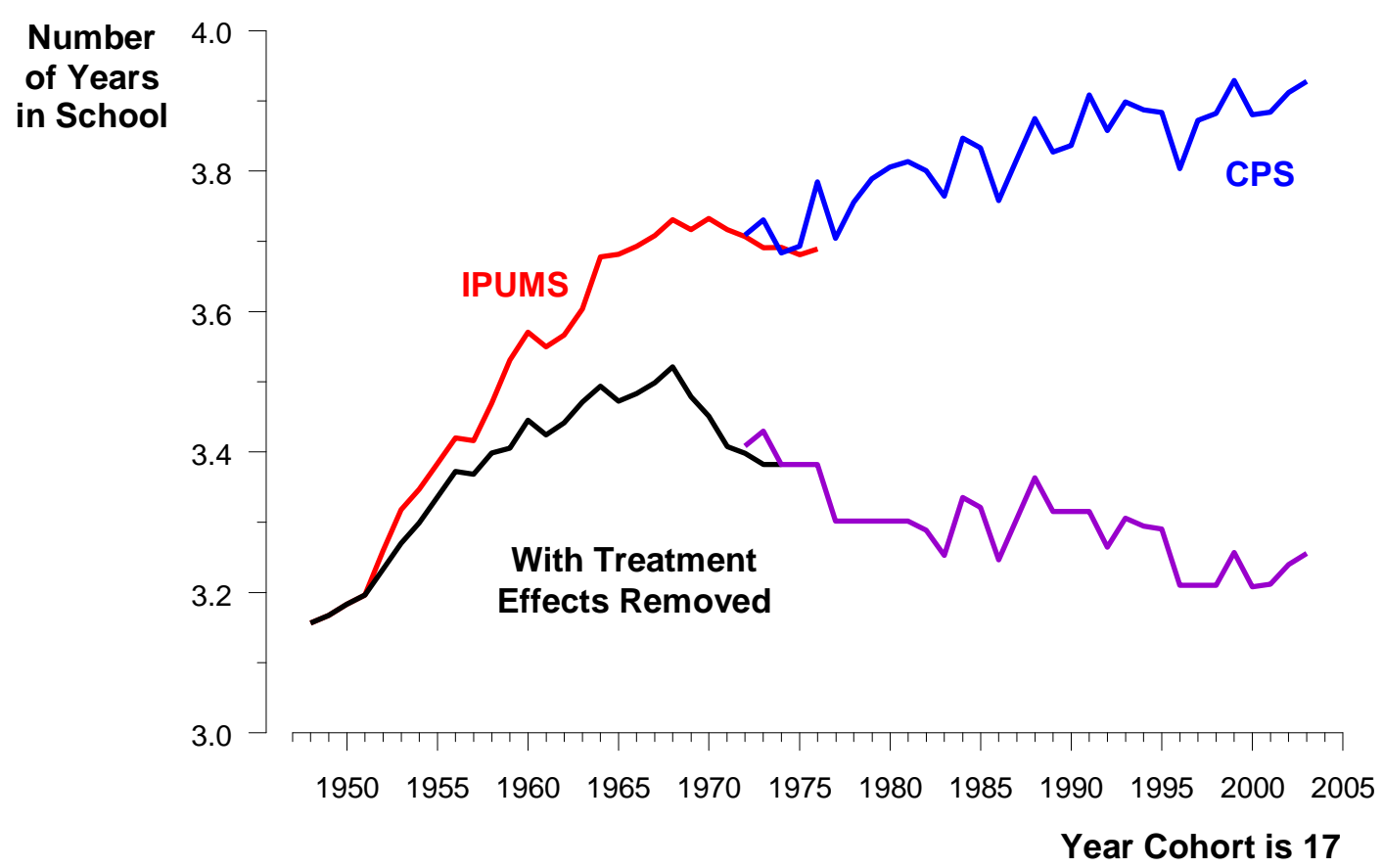

